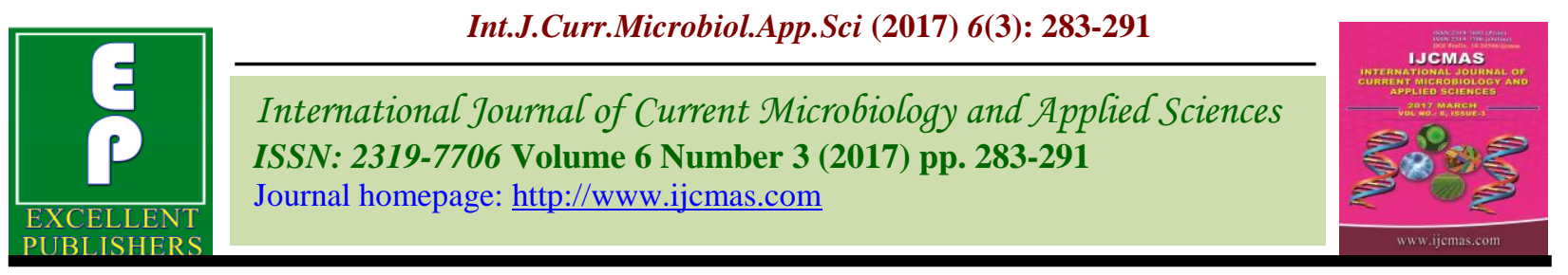

Original Research Article https://doi.org/10.20546/ijcmas.2017.603.031

\title{
Effect of Tillage and Phosphorus Fertilization of Wheat on Inorganic Soil Phosphorus Fractions under Wheat-Sorghum Cropping System
}

\author{
Dheeraj Panghaal*, P.S. Sangwan and S.B. Mittal \\ Department of Soil Science, CCS Haryana Agricultural University, \\ Hisar - 125 004, Haryana, India \\ *Corresponding author
}

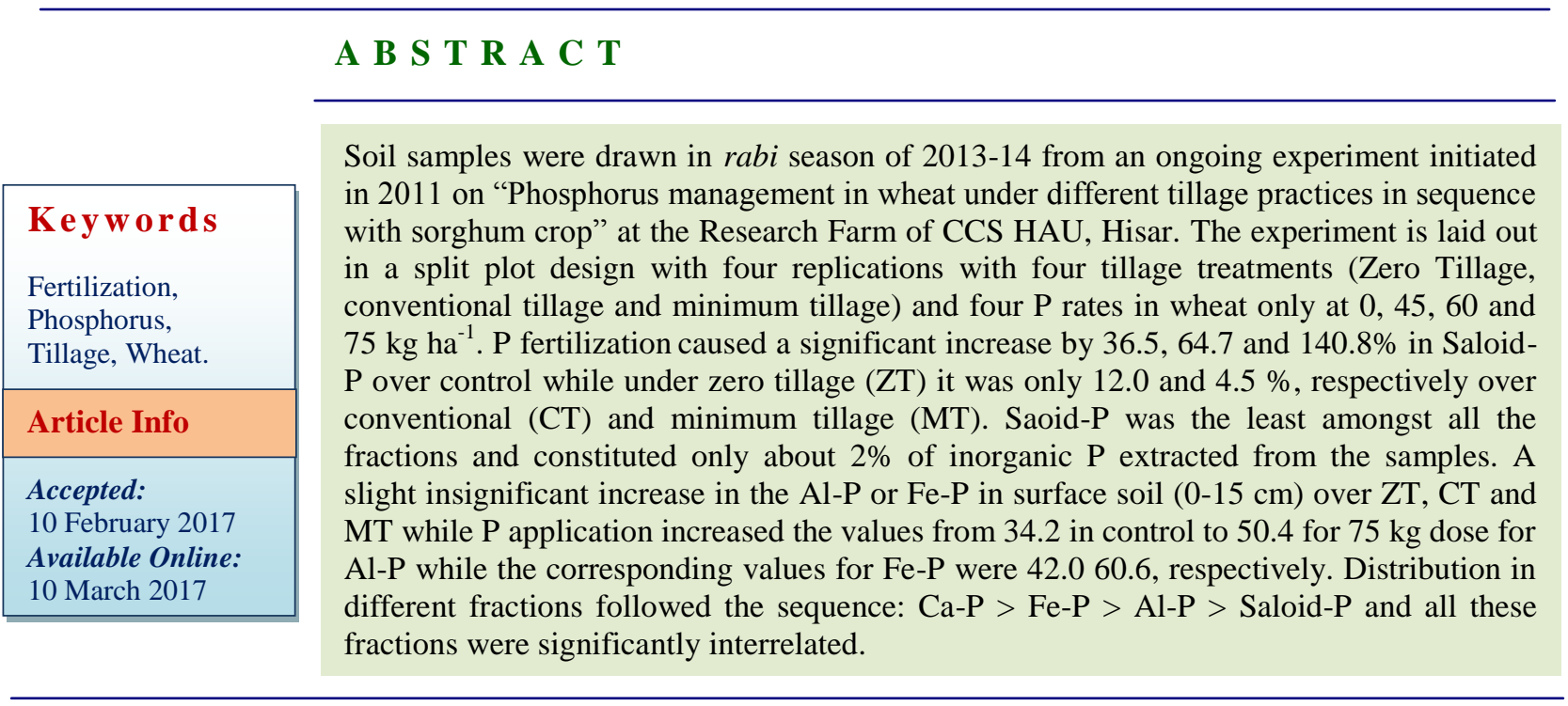

\section{Introduction}

A major part of phosphorus present in soil is not readily available to crops and its deficiency is a constraint to plant growth worldwide (Khan and Joergensen, 2009), particularly in arid and semi-arid regions. $\mathrm{P}$ fertilization of soils results in readily fixation as compounds of $\mathrm{Ca}$ or $\mathrm{Fe} / \mathrm{Al}$ depending upon the type of soil and with aging forms highly insoluble compounds (Brady and Weil, 2002). The supplementation by $\mathrm{P}$ fertilizers for optimum yields is governed by crop $\mathrm{P}$ requirements as well as on the extractable soil $\mathrm{P}$ and the $\mathrm{P}$ fixing capacity of the soil. Precise prediction of $\mathrm{P}$ fertilizer requirement is basic to sustainable agriculture and environment protection (Wang et al., 2001).

Intensive tillage without a cover of crop residues has caused a significant loss of soil organic matter and serious soil degradation, and has threatened sustainable crop production and food security (Liu et al., 2010).

Tillage may affect mineralization and decomposition of soil organic matter by changing the physical and chemical properties of soils and altering the diversity and activity 
of the soil microbial community and enzymes, which in turn affects the concentration and composition of soil $\mathrm{P}$ (Redel et al., 2011).

Conservation tillage reduces soil disturbance and mixing leftover crop residues may reduce erosion and conserve water. This change in the disposition of crop residues and adoption of low tillage practices may affect the cycling, distribution and dynamics of nutrient transformations in the soil (Hedley et al., 1982). In order to limit further degradation and the associated production losses, assessment of the impact of potential agronomic practices such as tillage and fertilization practices on crop production is crucial. Since P fertilizers are costly so any attempt on their economic use shall go a long way in maintenance of soil health but also be boon for the farmers.

Minimum or zero tillage is being advanced to economize on costs of cultivation and studies on distribution of applied $\mathrm{P}$ in various soil fractions is an attempt to understand the transformation and its release behavior under such situations and hence this study.

\section{Materials and Methods}

In rabi season of 2013-14 representative soil samples $(0-15$ and $15-30 \mathrm{~cm})$ were collected from an ongoing experiment on "phosphorus management in wheat under different tillage practices in sequence with sorghum crop".

This experiment, initiated in 2011 at the Research Farm, CCS Haryana Agricultural University, Hisar, has a split plot design with four replications. Three tillage treatments in main plots [(Zero tillage-ZT (Glyphosate at 3 $\mathrm{L} \mathrm{ha}^{-1}$ as desiccator at $10-15$ days before sowing); conventional tillage-CT (two cultivator + two tractor drawn harrowing followed by planking); and minimum tillageMT (one cultivator + one tractor drawn harrowing followed by planking)] and four $\mathrm{P}$ treatments in sub-plots at $0,45,60$ and $75 \mathrm{~kg}$ $\mathrm{ha}^{-1}$ applied in wheat only at the identical nitrogen fertilizer $\left(150 \mathrm{~kg} \mathrm{~N} \mathrm{ha}^{-1}\right)$. On these plots, sorghum was raised for fodder in kharif. Hisar has a semi-arid climate and situated at latitude $29^{\circ} 10^{\prime}$ North, longitude of $75^{\circ} 46^{\prime}$ East. The soil of the experimental site is Coarse loamy, calcareous, Typic Haplustepts. The relevant physico-chemical properties are given in Table 1. The soil is sandy loam in texture, alkaline in reaction, non-saline, medium in organic $\mathrm{C}$, low in available $\mathrm{N}$, medium in available $\mathrm{P}$ and high in available $\mathrm{K}$.

Moist subsamples were brought to the laboratory, air-dried and ground to pass through $2 \mathrm{~mm}$ sieve and stored in polyethylene bags for chemical analysis. $\mathrm{pH}$ and EC were determined in (1:2) soil: water suspension with the help of glass electrode $\mathrm{pH}$ meter and conductivity meter bridge, respectively as described by Richard (1954). Organic C was estimated by wet digestion method of Walkley and Black, 1934. Mechanical analysis was done using international pipette method (Piper, 1966). Available $\mathrm{N}$ was estimated by alkaline permanganate method (Subbiah and Asija, 1956).

Available $\mathrm{K}$ was extracted in $1 \mathrm{~N}$ ammonium acetate $(\mathrm{pH} \mathrm{7)}$ and determined on a flame photometer as described by Jackson (1973). The inorganic soil phosphorus fractionation was done according to Chang and Jackson (1957) as modified by Peterson and Corey (1966). Data obtained under various treatments were tabulated and statistically analyzed for their significance. Only for significant $F$ values, critical difference (CD) at $5 \%$ was calculated and comparing individual treatment effect compared (Cochran and Cox, 1957). 


\section{Results and Discussion}

\section{Phosphorus fractions}

Saloid-P: This pool represents loosely bound phosphorus and is easily available to plants. This form in surface samples was affected significantly by tillage practices and $P$ application while the interaction between the two factors was not significant (Table 2). Among various tillage practices, significantly highest Saloid-P (6.71) was under ZT followed by MT (6.42) and CT (5.99 $\left.\mathrm{mg} \mathrm{kg}^{-1}\right)$. Similarly, enhancing of phosphorus from 0 to $75 \mathrm{~kg} \quad \mathrm{P}_{2} \mathrm{O}_{5} \mathrm{ha}^{-1}$, resulted in a significant increase in this fraction with magnitude of 36.5, 64.7 and 140.8 per cent at 45, 60 and $75 \mathrm{~kg} \quad \mathrm{P}_{2} \mathrm{O}_{5}$ ha $^{-1}$ over control, respectively whereas under zero tillage it was only12.0 and $4.5 \%$ over CT and MT, respectively. Interaction between tillage and $\mathrm{P}$ application produced no effect.

At lower depth $(15-30 \mathrm{~cm})$, the results (Table 2) showed that the tillage systems failed to improve this $\mathrm{P}$ fraction significantly. The highest value (5.22) was under ZT followed by CT (4.96) and MT (4.79 $\mathrm{mg} \mathrm{kg}^{-1}$ ). As expected, $\mathrm{P}$ fertilization however, influenced significantly the Saloid- P levels. The highest rate of $\mathrm{P}$ application $\left(75 \mathrm{~kg} \mathrm{P}_{2} \mathrm{O}_{5} \mathrm{ha}^{-1}\right)$ resulted in significantly higher Saloid- $P$ (6.58) values as compared to lower $\mathrm{P}$ rates (4.42- $5.71 \mathrm{mg} \mathrm{kg}^{-1}$ ) and the control plots recording the lowest value of $3.24 \mathrm{mg} \mathrm{kg}^{-1}$.

The magnitude of increase in Saloid-P under ZT was 5.2 and $8.9 \%$ over CT and MT, respectively. Further, the values of Saloid-P were higher in the surface as compared to the subsurface soil samples under various treatments. It was also observed that the Saloid bound $\mathrm{P}$ is the least amongst the fractions and on an average constituted only about $2 \%$ of total inorganic $\mathrm{P}$ extracted from the soil.
Aluminium-P: A slight increase in the Al-P of the soil $(0-15 \mathrm{~cm})$ over ZT (40.33), CT (41.25) and MT (42.17 $\mathrm{mg} \mathrm{kg}^{-1}$ ) but no significant difference in Al-P under different tillage systems (Table 3), was recorded. Application of $\mathrm{P}$ up to the highest rate $(75 \mathrm{~kg}$ $\mathrm{ha}^{-1}$ ) significantly increased the Al-P in the soil recording the highest value $\left(50.44 \mathrm{mg} \mathrm{kg}^{-1}\right)$. The interaction both was not significant. The magnitude of increase in Al-P fraction under MT was 2.3 and $4.5 \%$ over CT and ZT while it was 9.4, 25.3 and $47.4 \%$ at 45,60 and $75 \mathrm{~kg}$ $\mathrm{P}_{2} \mathrm{O}_{5} \mathrm{ha}^{-1}$ over control, respectively. As found in surface, interaction effect of tillage and $\mathrm{P}$ was insignificant effect for lower depth (Table 7). The highest Al-P was recorded in MT treatment (28.50) while the lowest was recorded for CT (28.01) but both were statistically at par to ZT (28.09 $\left.\mathrm{mg} \mathrm{kg}^{-1}\right)$.

Increasing the rate of $\mathrm{P}$ application significantly increased Al-P over control and lower $\mathrm{P}$ rates and naturally higher value of Al-P was for $75 \mathrm{~kg} \mathrm{P}_{2} \mathrm{O}_{5} \mathrm{ha}^{-1}\left(38.88 \mathrm{mg} \mathrm{kg}^{-1}\right)$ as compared to lower P levels (19.67-32.12 $\left.\mathrm{mg} \mathrm{kg}{ }^{-1}\right)$. This increase in Al-P fraction was $12.4,63.3$ and $97.6 \%$ at 45,60 and $75 \mathrm{~kg}$ $\mathrm{P}_{2} \mathrm{O}_{5} \mathrm{ha}^{-1}$, respectively over control which accounted for almost double of the amount recorded in surface samples at the corresponding level of $75 \mathrm{~kg} \mathrm{P}_{2} \mathrm{O}_{5} \mathrm{ha}^{-1}$. Further, Al-P values were higher than those for Saloid-P in surface or sub surface samples. This fractional form of $\mathrm{P}$ accounted for $12.3 \%$ of total inorganic soil $\mathrm{P}$ extracted.

Iron-P: The results (Table 4) also did not reveal any significant differences in $\mathrm{Fe}-\mathrm{P}$ between the three tillage systems. In surface samples it decreased in the order: ZT (51.83) $\left.<\operatorname{MT}(52.26)<\mathrm{CT}(52.83 \mathrm{mg} \mathrm{kg})^{-1}\right)$. Comparing the values for different rates of added $\mathrm{P}$, fertilized plots yielded significantly higher Fe-P over control or lower rate. Consequently, highest and significant value was for plots receiving $75 \mathrm{~kg} \mathrm{P}_{2} \mathrm{O}_{5} \mathrm{ha}^{-1}$. The 
magnitude of increase in Fe-P fraction was $21.9,32.0$ and $44.2 \%$ at 45,60 and $75 \mathrm{~kg}$ $\mathrm{P}_{2} \mathrm{O}_{5}$ ha $^{-1}$ over control, respectively. This form of $\mathrm{P}$ fraction accounted for, on an average, $15.6 \%$ of total inorganic $\mathrm{P}$ extracted from the soil. Non significant tillage $\mathrm{X}$ phosphorus interaction was observed for Fe-P content in surface soil.

At lower depth $(15-30 \mathrm{~cm})$ also, same trend as in surface in Fe-P content under various treatments was recorded except that the values were on the lower side (Table 4). The range of $\mathrm{Fe}-\mathrm{P}$ content was 44.75-45.43 and 40.56-50.57 mg kg-1 under various tillage and $\mathrm{P}$ applications, respectively. The magnitude of increase in Fe-P fraction was 7.3, 12.6 and $24.7 \%$ at 45,60 and $75 \mathrm{~kg} \mathrm{P}_{2} \mathrm{O}_{5} \mathrm{ha}^{-1}$ over control, respectively. It was revealed that $\mathrm{Fe}$ $\mathrm{P}$ content in soil was in the order: Saloid-P $\mathrm{Al}-\mathrm{P}<\mathrm{Fe}-\mathrm{P}$ at both corresponding surface and subsurface depths.

Calcium-P: Except Saloid-P, like other inorganic fractions, $\mathrm{Ca}-\mathrm{P}$ with tillage alone and in combination with applied $\mathrm{P}$, did not vary significantly effect on $\mathrm{Ca}-\mathrm{P}$ values in surface soil samples (Table 5). For tillage, the order was: MT (236.8 $\left.\mathrm{mg} \mathrm{kg}^{-1}\right)>\mathrm{ZT}(235.8$ $\left.\mathrm{mg} \mathrm{kg}^{-1}\right)>\mathrm{CT}\left(234.3 \mathrm{mg} \mathrm{kg}^{-1}\right)$. The effect of rate of $\mathrm{P}$ applied on $\mathrm{Ca}-\mathrm{P}$ was significant at all levels with $75 \mathrm{~kg} \mathrm{P}_{2} \mathrm{O}_{5} \mathrm{ha}^{-1}$ producing highest values (260.0) than the other rates of $P$ applied (224.0 and $245.6 \mathrm{mg} \mathrm{kg}^{-1}$, respectively at 45 and $60 \mathrm{~kg} \mathrm{P}_{2} \mathrm{O}_{5} \mathrm{ha}^{-1}$ ) and the control (213.0 $\left.\mathrm{mg} \mathrm{kg}^{-1}\right)$.

The magnitude of increase in Ca-P was 5.1, 15.3 and $22.0 \%$ at 45,60 and $75 \mathrm{~kg} \mathrm{P}_{2} \mathrm{O}_{5} \mathrm{ha}^{-1}$ over control, respectively and this form of $\mathrm{P}$ relatively constituted $70 \%$ of total inorganic $\mathrm{P}$ fractions extracted from the soil. Unlike tillage system, phosphorus application had a significant impact on Ca-P in subsurface soil samples. Values increased in the order: 142.6 $>160.7>177.4>199.4 \mathrm{mg} \mathrm{kg}^{-1}$ at $0,45,60$ and $75 \mathrm{~kg} \mathrm{P}_{2} \mathrm{O}_{5} \mathrm{ha}^{-1}$, respectively. The values of $\mathrm{Ca}-\mathrm{P}$ were also significantly different between any two successive levels of $\mathrm{P}$ (Table $5)$.

From the results, it was very much evident that distribution of inorganic $\mathrm{P}$ in different fractions followed the sequence: $\mathrm{Ca}-\mathrm{P}>\mathrm{Fe}-\mathrm{P}$ $>$ Al-P > Saloid-P. A perusal of data further indicated that $\mathrm{Ca}-\mathrm{P}$ represented around $70 \%$ of total inorganic $\mathrm{P}$ extracted in the soil while the values for Fe-P, Al-P and Saloid-P were $15.6,12.3$ and $2.0 \%$, respectively. Increase in the level of $\mathrm{P}$ application significantly increased all the inorganic soil $\mathrm{P}$ fractions values over control and lower P levels.

Table.1 Physico-chemical properties of soil of the experimental site at initiation

\begin{tabular}{|lcc|}
\hline \multirow{2}{*}{ Soil property } & \multicolumn{2}{c|}{ Soil depth (cm) } \\
\cline { 2 - 3 } & $\mathbf{0 - 1 5}$ & $\mathbf{1 5 - 3 0}$ \\
\hline Sand (\%) & 69.8 & 71.6 \\
Silt $(\%)$ & 16.4 & 12.8 \\
Clay $(\%)$ & 13.8 & 15.6 \\
Textural class & Sandy loam & Sandy loam \\
$\mathrm{pH}_{(1: 2)}$ & 8.20 & 8.12 \\
$\mathrm{EC}_{(1: 2)} \mathrm{dS} \mathrm{m}{ }^{-1}$ & 0.52 & 0.54 \\
Organic C $(\%)$ & 0.48 & 0.34 \\
Available N $\left(\mathrm{kg} \mathrm{ha}^{-1}\right)$ & 140 & 126 \\
Available P $\left(\mathrm{kg} \mathrm{ha}^{-1}\right)$ & 14.6 & 11.7 \\
Available K $\left(\mathrm{kg} \mathrm{ha}^{-1}\right)$ & 450 & 478 \\
\hline
\end{tabular}


Table.2 Saloid-P $\left(\mathrm{mg} \mathrm{kg}^{-1}\right)$ in soil as influenced by tillage and $\mathrm{P}$ application

\begin{tabular}{|c|c|c|c|c|c|}
\hline \multirow{2}{*}{ Tillage } & \multicolumn{4}{|c|}{$\mathrm{P}$ level $\left(\mathrm{kg} \mathrm{P}_{2} \mathrm{O}_{5} \mathrm{ha}^{-1}\right)$} & \multirow{2}{*}{ Mean } \\
\hline & $\mathbf{0}$ & 45 & 60 & 75 & \\
\hline ZT & 4.50 & 6.10 & 6.50 & 9.73 & 6.71 \\
\hline MT & 3.93 & 5.33 & 6.83 & 9.57 & 6.42 \\
\hline CT & 3.46 & 4.83 & 6.30 & 9.36 & 5.99 \\
\hline Mean & 3.97 & 5.42 & 6.54 & 9.56 & \\
\hline $\mathrm{CD}(\mathrm{p}=0.05)$ & Tillą & P lev & ; Tillas & & \\
\hline & & & & & \\
\hline$\overline{\mathrm{ZT}}$ & 3.57 & 4.53 & 6.13 & 6.63 & 5.22 \\
\hline MT & 2.70 & 4.37 & 5.50 & 6.60 & 4.79 \\
\hline CT & 3.47 & 4.37 & 5.50 & 6.50 & 4.96 \\
\hline Mean & 3.24 & 4.42 & 5.71 & 6.58 & \\
\hline $\mathrm{CD}(\mathrm{p}=0.05)$ & Tillą & P leve & Tillag & & \\
\hline
\end{tabular}

Table.3 Al-P $\left(\mathrm{mg} \mathrm{kg}^{-1}\right)$ in soil as influenced by tillage and $\mathrm{P}$ application

\begin{tabular}{|c|c|c|c|c|c|}
\hline \multirow{2}{*}{ Tillage } & \multicolumn{4}{|c|}{ P level $\left(\mathrm{kg} \mathrm{P}_{2} \mathrm{O}_{5} \mathrm{ha}^{-1}\right)$} & \multirow{2}{*}{ Mean } \\
\hline & $\mathbf{0}$ & 45 & 60 & 75 & \\
\hline ZT & 32.68 & 36.34 & 43.00 & 49.33 & 40.33 \\
\hline MT & 36.32 & 39.33 & 42.36 & 50.67 & 42.17 \\
\hline CT & 33.66 & 36.65 & 43.30 & 51.31 & 41.25 \\
\hline Mean & 34.22 & 37.44 & 42.89 & 50.44 & \\
\hline $\mathrm{CD}(\mathrm{p}=0.05)$ & \multicolumn{5}{|c|}{$\begin{array}{c}\text { Tillage: NS ; P level: } 1.94 \text {; Tillage x P: NS } \\
\text { Subsurface }\end{array}$} \\
\hline ZT & 19.36 & 21.68 & 32.69 & 38.62 & 28.09 \\
\hline MT & 20.33 & 22.67 & 31.33 & 39.66 & 28.50 \\
\hline CT & 19.32 & 22.00 & 32.35 & 38.36 & 28.01 \\
\hline Mean & 19.67 & 22.12 & 32.12 & 38.88 & \\
\hline $\mathrm{CD}(\mathrm{p}=0.05)$ & \multicolumn{5}{|c|}{ Tillage: NS ; P level: 1.08 ; Tillage x P: NS } \\
\hline
\end{tabular}

Table.4 Fe-P $\left(\mathrm{mg} \mathrm{kg}^{-1}\right)$ in soil as influenced by tillage and $\mathrm{P}$ application

\begin{tabular}{|c|c|c|c|c|c|}
\hline \multirow{2}{*}{ Tillage } & \multicolumn{4}{|c|}{$P$ level $\left(\mathrm{kg} \mathrm{P}_{2} \mathrm{O}_{5} \mathrm{ha}^{-1}\right)$} & \multirow{2}{*}{ Mean } \\
\hline & $\mathbf{0}$ & 45 & 60 & 75 & \\
\hline ZT & 43.00 & 50.66 & 54.00 & 59.64 & 51.83 \\
\hline MT & 41.33 & 50.68 & 56.69 & 60.32 & 52.26 \\
\hline CT & 41.65 & 52.32 & 55.67 & 61.66 & 52.83 \\
\hline Mean & 41.99 & 51.22 & 55.45 & 60.56 & \\
\hline $\mathrm{CD}(\mathrm{p}=0.05)$ & \multicolumn{5}{|c|}{$\begin{array}{c}\text { Tillage: NS ; P level: } 1.88 \text {; Tillage x P: NS } \\
\text { Subsurface }\end{array}$} \\
\hline ZT & 39.67 & 43.30 & 45.35 & 50.67 & 44.75 \\
\hline MT & 40.29 & 43.00 & 45.98 & 51.00 & 45.07 \\
\hline CT & 41.72 & 44.31 & 45.65 & 50.05 & 45.43 \\
\hline Mean & 40.56 & 43.54 & 45.66 & 50.57 & \\
\hline $\mathrm{CD}(\mathrm{p}=0.05)$ & \multicolumn{5}{|c|}{ Tillage: NS ; P level: 1.09 ; Tillage x P: NS } \\
\hline
\end{tabular}


Table.5 Ca-P (mg kg-1) in surface soil as influenced by tillage and P application

\begin{tabular}{|c|c|c|c|c|c|}
\hline \multirow{2}{*}{ Tillage } & \multicolumn{4}{|c|}{ P level $\left(\operatorname{kg~P}_{2} \mathrm{O}_{5} \mathrm{ha}^{-1}\right)$} & \multirow{2}{*}{ Mean } \\
\hline & $\mathbf{0}$ & 45 & 60 & 75 & \\
\hline$\overline{Z T}$ & 212.7 & 223.7 & 247.3 & 259.6 & 235.8 \\
\hline MT & 216.0 & 224.3 & 247.6 & 259.3 & 236.8 \\
\hline CT & 210.3 & 224.0 & 241.7 & 261.1 & 234.3 \\
\hline Mean & 213.0 & 224.0 & 245.6 & 260.0 & \\
\hline $\mathrm{CD}(\mathrm{p}=0.05)$ & \multicolumn{5}{|c|}{$\begin{array}{c}\text { Tillage: NS ; P level: } 4.0 \text {; Tillage x P: NS } \\
\text { Subsurface }\end{array}$} \\
\hline ZT & 144.3 & 160.7 & 180.4 & 198.3 & 170.9 \\
\hline MT & 142.3 & 161.0 & 173.0 & 197.7 & 168.5 \\
\hline CT & 141.3 & 160.3 & 178.7 & 202.1 & 170.6 \\
\hline Mean & 142.6 & 160.7 & 177.4 & 199.4 & \\
\hline $\mathrm{CD}(\mathrm{p}=0.05)$ & \multicolumn{5}{|c|}{ Tillage: NS; P level: 2.5; Tillage x P: NS } \\
\hline
\end{tabular}

Saloid-P in surface samples was affected significantly by tillage practices and $\mathrm{P}$ application but the interaction between these factors was not significant. Saloid-P represented around $2 \%$ of total inorganic $\mathrm{P}$ extracted from the soil. Among various tillage practices, significantly highest Saloid-P fraction was under ZT followed by MT and CT. Application of $\mathrm{P}$ cause significant increase in this fraction. It was due to relatively more transformation of native $\mathrm{P}$ (Tomar, 2003). Increase in $P$ rate gradually increased the $\mathrm{P}$ concentration in different fractions due to higher $\mathrm{P}$ fixation with increase in the levels of $\mathrm{P}$ application (Manimaran, 2014). Further, Saloid-P values were more in surface as compared to subsurface soil perhaps due to slow transformation of soluble forms of $\mathrm{P}$ added into sparingly soluble forms with time. This find supported from the findings of Tiwari et al., (2012) and Sharma et al., (2012). Also, Saloid bound $\mathrm{P}$ values were lowest among the other fractions and had also been previously reported (Adhikari and Si, 1994; Pati Ram and Mukhopadhyay, 2008) in different soil types.

The Al-P values in both surface as well as subsurface soils were significantly affected by
$\mathrm{P}$ application. Higher value of Al-P was at 75 $\mathrm{kg} \mathrm{P}_{2} \mathrm{O}_{5} \mathrm{ha}^{-1}$ as compared to its lower application rate. This fraction was about $12.3 \%$ of the total inorganic $\mathrm{P}$ extracted. Further, Al-P values are higher than Saloid-P at both depths and gets support from Tandon (1987). The decrease in Al-P in subsurface could be attributed to the lower $\mathrm{Al}_{2} \mathrm{O}_{3}$ content in profile depth (Kalaivanan and Sudhir, 2012).

Comparing the $\mathrm{P}$ rates, fertilization significantly enhanced Fe-P over control as well as between the various levels and significantly highest value was for $75 \mathrm{~kg} \mathrm{P}_{2} \mathrm{O}_{5}$ $\mathrm{ha}^{-1}$ rate. Fe-P on an average represented $15.6 \%$ of total inorganic P extracted. These results are in line with those reported by Manimaran (2014) who reported that concentration of $\mathrm{Ca}-\mathrm{P}$ and $\mathrm{Fe}-\mathrm{P}$ increased with increase in rate of applied $\mathrm{P}$ and the increase in $\mathrm{Ca}-\mathrm{P}$ and $\mathrm{Fe}-\mathrm{P}$ was attributed to transformation of a larger proportion of applied $\mathrm{P}$ to $\mathrm{Ca}-\mathrm{P}$ which further shifted to $\mathrm{Fe}-$ $\mathrm{P}$ with time. It was reported that $\mathrm{P}$ fractions were in the order: Saloid-P $<$ Al-P $<$ Fe-P in surface and sub-surface. Soluble or loosely bound $\mathrm{P}$, Al-P, and Fe-P were the main fractions contributing to plant-available $\mathrm{P}$ but Fe-P and Al-P were the two major 
contributors (Wang and Zhang, 2012; Malakar et al., 2015). At lower $(15-30 \mathrm{~cm})$ depth also, similar trend of surface Fe-P content under various treatments was recorded except lower values. The amounts of $\mathrm{Fe}$ and $\mathrm{Al}$ bound $\mathrm{P}$ can be ascribed to the presence of sesquioxides which might have transformed a portion of added soluble $\mathrm{P}$. Similar results were reported by Harrell and Wang (2006) in calcareous soil from Louisiana.

The effect of the variation in rate of $\mathrm{P}$ applied on $\mathrm{Ca}-\mathrm{P}$ was significant at all the levels with $75 \mathrm{~kg} \mathrm{P}_{2} \mathrm{O}_{5}$ ha $^{-1}$ producing significantly higher values than the other rates at both depths and the values were significantly different when successive rate were compared. It was found that on an average, Ca-P constituted $70.2 \%$ of total inorganic $\mathrm{P}$ fraction extracted from the soil. Corroborative findings have also been reported by Devra et al., (2014) and Manimaran (2014).

In the present investigation, distribution of inorganic $\mathrm{P}$ fractions followed the sequence: Ca-P > Fe-P > Al-P > Saloid-P. Dominance of $\mathrm{Ca}-\mathrm{P}$ in these soils is attributed to the calcareous nature of the soil as soluble or exchangeable $\mathrm{Ca}$ on reaction with soluble $\mathrm{P}$ resulted in the formation of sparingly soluble salts such as Ca-phosphate. Similar observation have been reported by several authors (Kalaivanan and Sudhir, 2012; Tiwari et al., 2012; Sharma et al., 2012; Dubey et al., 2014; Sarkar et al., 2014; Gopinath et al., 2015; Sanyal et al., 2015).

The insignificant changes in various fractions of $\mathrm{P}$ due to tillage practices are explained by the fact that there organic $\mathrm{C}$ content either in surface or subsurface was not influenced significantly neither by tillage practices nor $\mathrm{P}$ fertilization (Panghaal, 2015). This is important as easily oxidizable organic $\mathrm{C}$ is key to various soil chemical processes through release of organic compounds during decomposition which may solublize the sparingly soluble compounds especially $\mathrm{P}$ which is existing as insoluble $\mathrm{Ca}$ - phosphates. Under aridic climatic conditions prevailing in the area, build up of organic $\mathrm{C}$ is very slow (Antil et al., 2011).

\section{Acknowledgement}

The authors are thankful to CCS Haryana Agricultural University, Hisar for providing all the necessary facilities during the course of this work undertaken for Masters Degree of Dheeraj Panghaal. Special thanks are due to Dr. V. K. Phogat, Professor and Head, Department of Soil Science for going through the manuscript and offering his valuable suggestions.

\section{References}

Adhikari, M. and Si, S.K. 1994. Distribution of inorganic phosphate fractions in some acid soils of West Bengal. $J$. Indian Soc. Soil Sci., 42: 459-61.

Antil, R.S., Narwal, R.P., Singh, B. and Singh, J.P. 2011. Long-term effects of FYM and $\mathrm{N}$ application on soil health and productivity under pearl milletwheat cropping system. Indian J. Fert., 7: 14-32.

Chang, S.C. and Jackson, M.L. 1957. Fractionation of soil phosphorus. Soil Sci., 84: 133-144.

Cochran, W.D. and Cox, G.M. 1957. Experimental Designs, $2^{\text {nd }}$ edition Willey, New York.

Devra, P., Yadav, S.R. and Gulati, I.J. 2014. Distribution of different phosphorus fractions and their relationship with soil properties in western plains of Rajasthan. Agropedol., 24: 20-28.

Dubey, L., Dwivedi, A.K., Singh, H.V., Verma, S. and Singh, J. 2014. Effect of fertilizers and manure on profile 
distribution of phosphorus and crop yield. Bioinfolet, 11(2C): 629-631.

Gopinath, A., Chandramohanakumar, N., Padmalal, D. and Muraleedharan Nair, S. 2015. Distributional characteristics in fractionation of phosphorus in a coral reef sedimentary environment. Chem. Spec. Bioavail., 20: 149-159.

Harrell, D.L. and Wang, J.J. 2006. Fractionation and sorption of inorganic phosphorus in Louisiana calcareous soils. Soil Sci., 171: 39-51.

Hedley, M.J., Stewart, J.W.B. and Chauhan, B.S. 1982. Changes in inorganic and organic phosphorus induced by cultivation practices and laboratory incubations. Soil Sci. Soc. Am. J., 46: 970-976.

Jackson, M.L. 1973. Soil chemical analysis. Prentice Hall of India Pvt. Ltd, New Delhi, India.

Kalaivanan, D. and Sudhir, K. 2012. Phosphorus fractions of selected banana growing soils of India and their relationships with soil characteristics. Mysore J. Agric. Sci., 46: 73-79.

Khan, K.S. and Joergensen, R.G. 2009. Changes in microbial biomass and $\mathrm{P}$ fractions in biogenic household waste compost amended with inorganic $\mathrm{P}$ fertilizers. Bioresource Tech., 100: 303309.

Liu, X.B., Zhang, X.Y., Wang, Y.X., Sui, Y.Y., Zhang, S.L., Herbert, S.J. and Ding, G. 2010. Soil degradation: A problem threatening the sustainable development of agriculture in Northeast China. Plant Soil Environ., 56: 87-97.

Malakar, H., Ghosh, D., Chatterjee, S. and Debnath, A. 2015. Inorganic and organic soil phosphorus fractions in humid tropical tea plantation of West Bengal, India. The Bioscan., 10(1): 313-318.

Manimaran, M. 2014. Dynamics of phosphorus in soil under the influence of inorganic phosphorus supply. Int. J. Info. Res. Rev., 12: 79-80.

Panghaal, D. 2015. Effect of tillage practices and $\mathrm{P}$ fertilization on soil inorganic $\mathrm{P}$ fractions, yield and nutrient uptake by wheat. M.Sc. Thesis submitted to Chaudhary Charan Singh Haryana Agricultural University, Hisar, India.

Pati, R. and Mukhopadhyay, D. 2008. Inorganic phosphorus fractions in some acid soils under terai situations of West Bengal. Res. Crops, 9: 57-60.

Peterson, G.W. and Corey, R.B. 1966. A modified Chang and Jackson procedure for routine fractionation of inorganic soil phosphates. Soil Sci. Soc. Am. J., 30: 563-565.

Piper, C.S. 1966. Soil and plant analysis. Hans Publisher, Bombay.

Redel, Y.D., Escudey, M., Alvear, M., Conrad, J. and Borie, F. 2011. Effects of tillage and crop rotation on chemical phosphorus forms and some related biological activities in a Chilean ultisol. Soil Use Manage, 27: 221-228.

Richards, L.A. 1954. Diagnosis and improvement of saline and alkali soils. U.S. Salinity Laboratory, U.S. Dep. Agric. Hand Book 60.

Sanyal, S.K., Dwivedi, B.S., Singh, V.K., Majumdar, K., Datta, S.C., Pattanayak, S.K. and Annapurna, K. 2015. Phosphorus in relation to dominant cropping sequences in India: chemistry, fertility relations and management options. Curr. Sci., 108: 1262-1270.

Sarkar, D., Haldar, A. and Mandal, D. 2014. Forms of phosphorus in relation to soil maturity along a toposequence under hot, dry, subhumid agro-ecological subregion of West Bengal. J. Indian Soc. Soil Sci., 62: 29-37.

Sharma, P., Singh, G. and Singh, R.P. 2012. Conservation tillage, optimal water and organic nutrient supply enhance soil microbial activities during wheat 
cultivation. Braz. J. Microbiol., 42: 531542.

Subbiah, B.V. and Asija, G.L. 1956. A rapid procedure for the determination of available nitrogen in soils. Curr. Sci., 25: 259-260.

Tiwari, H.N., Singh, D. and Prakesh, V. 2012. Fractions of soil phosphorus under different cropping patterns. Ann. Plant Soil Res., 14: 173-174.

Tomar, N.K. 2003. Effect of soil properties on the kinetics of $\mathrm{P}$ description on acid soils. J. Indian Soc. Soil Sci., 51: 508511.

Walkley, A. and Black, C.A. 1934. An examination of the method of determination of organic matter and a proposed modification of the chromic acid titration method. Soil Sci., 37: 2934.

Wang, C.Q., Wei, C.M., Li, T.Q. and Sun, F.Q. 2001. Effect of different zero tillage on the crop yield and soil property. J. Sichuan Agri. Univ., 19: $152-155$.

Wang, Y. and Zhang, Y. 2012. Soil inorganic phosphorus fractionation and availability under greenhouse subsurface irrigation. Comm. Soil Sci. Plant Anal., 43: 519-532.

\section{How to cite this article:}

Dheeraj Panghaal, P.S. Sangwan and Mittal, S.B. 2017. Effect of Tillage and Phosphorus Fertilization of Wheat on Inorganic Soil Phosphorus Fractions under Wheat-Sorghum Cropping System. Int.J.Curr.Microbiol.App.Sci. 6(3): 283-291. doi: https://doi.org/10.20546/ijcmas.2017.603.031 